\title{
NEWFOUNDLAND'S WORKERS' COMPENSATION LEGISLATION: CONSTITUTIONAL AND CONFLICT OF LAWS ISSUES ARISING FROM OFFSHORE OIL AND GAS EXPLORATION
}

\author{
ERROL P. MENDES*
}

In the light of the "Ocean Ranger" marine disaster off the coast of Newfoundland in February, 1982, this article examines three aspects of the legal regime governing workers' claims arising from offshore accidents: whether Newfoundland's Workers' Compensation Act may constitutionally be applied to such claims; the effect of conflict of laws rules upon the availability of alternative tort actions in Canadian jurisdictions; and the availability of alternative actions in United States courts. In an appendix, the author draws attention to recent legislative developments in this field.

\section{INTRODUCTION}

One of the reasons why problems arise in the application of Workers' Compensation legislation ${ }^{1}$ to offshore oil and gas exploration is that offshore oil and gas exploration cuts across many jurisdictional boundaries. Matters are further complicated by the fact that the most promising exploration fields, such as the Hibernia field, are far beyond the land boundaries and territorial seas ${ }^{2}$ of the nearest province or country. In this area, one is likely to encounter the following situation:

(1) The semi-submersible and other types of drilling rigs used in exploration are likely to be owned and operated by Canadian subsidiaries of American-based companies such as Ocean Drilling and Exploration International Corporation, which has its headquarters in New Orleans but is incorporated in Delaware.

(2) The rigs are hired by Canadian-owned companies such as PetroCanada or by Canadian subsidiaries of U.S. parent companies. Most of these Canadian exploration companies are headquartered in either Toronto or Calgary. These companies shall be termed "rig-operators" for the purposes of this paper.

(3) Several other employers of offshore workers may be involved in providing specialized services to the rig-owner or operator. These employers may be incoporated, registered or based anywhere in the world.

(4) Although the employers mentioned above may be incorporated or headquartered anywhere in the world, their local base of operations is probably St. John's, Newfoundland. Some of the employers may be regis-

* Assistant Professor, Faculty of Law, University of Alberta.

1. For Newfoundland's workers' compensation legislation, see Workers' Compensation Act, R.S.N. 1970, c. 403, as am. S.N. 1971 No. 79; 1973 No. $115 ; 1974$ No. $72 ; 1975$ No. 43; 1975-76 No. 42; Workers' Compensation Board Regulations 1974, Newfoundland Gazette, May 21, 1974; and Workers' Compensation Board Regulations Amendment, Newfoundland Gazette, March 9, 1979.

2. Under the provisions of the Territorial Sea and Fishing Zones Act, S.C. 1964, c. 22, s. 3(1), Canada claimed a three mile territorial sea to be measured from the low watermark or from straight or other pre-existing baselines. In 1970 the federal Parliament amended the Act to create a 12-mile territorial sea; R.S.C. 1970, c. T-7, s. 3(1) as am., R.S.C. 1970 (1st Supp.), c. 45, c. 3(1). The United Nations has confirmed the legality of a 12-mile territorial sea in the new Law of the Sea Convention recently passed by the General Assembly. See Edmonton Journal, May 1, 1982. 
tered under Newfoundland's Companies Act.

(5) The workers on the offshore drilling rigs may be residents of Newfoundland whose contracts of employment were entered into in Newfoundland or they may be residents of another province or country who have entered their contracts of employment in Calgary, Houston, New Orleans or elsewhere. Most provincial Workers' Compensation legislation covers only those workers who are resident in or usually employed in the province, apart from special circumstances and exceptions. The Workers' Compensation Board of Newfoundland has asserted that there is mandatory coverage for employers operating in the offshore, ${ }^{3}$ and that the legislation could possibly cover even non-residents who were hired in Newfoundland or were paid through their employers' local offices in Newfoundland or who travelled to work on the rigs from points in Newfoundland. ${ }^{4}$

(6) The semi-submersible and other types of rigs anchored in offshore areas such as the Hibernia field are considered to be operating in international waters commonly called the High Seas. ${ }^{5}$ Because such rigs are owned by U.S. parent companies, they are likely to be of U.S. registry. ${ }^{6}$

In view of the above structure, deciding which (if any) jurisdiction's law would govern Workers' Compensation disputes would seem an insurmountable task at first sight. There is even more uncertainty concerning which government has general regulatory authority in areas such as the Hibernia field. ${ }^{7}$ Until a settlement is reached between the Government of Newfoundland and the Government of Canada, or until the issue is settled by the Supreme Court of Canada, the uncertainty and confusion will continue. Both governments carry on inspections of drilling operations on these rigs. However, neither level of government carries on inspections that relate to marine safety on the rigs operating in the Hibernia area.

3. Financial Post, February 27, 1982, p. 6. In an interview with the writer on April 14, 1982 , an official from Newfoundland's Workers' Compensation Board confirmed that the Board considers employment on the rigs to be within the mandatory coverage provisions of the Act. Employment on the offshore rigs seems to come within the provisions of Section 3(1)(e) and (f) of the Act. Subsections (e) and (f) state:

(1) This Part applies to employers and workers in or about ...

(e) the operation of docks, wharves, boats, ships, tugs, dredges, ferries;

(f) navigation, stevedoring.

"Navigation" is defined in Section $2(v)$ as follows:

(v) "Navigation" includes all kinds of operations carried on by means of a "ship" as defined by the Canada Shipping Act.

4. Infra n. 33.

5. The 1958 Geneva Convention on the High Seas, U.N. Doc. A/Conf. 131/53, signed by Canada on April 29,1958, stipulates that the high seas comprises all the bodies of water not included in internal waters and the territorial sea. The new Law of the Sea Convention makes the high seas begin at the outer limit of the exclusive economic zone or the archipelago waters of an archipelagic state. Under the new Law of the Sea Convention, the exclusive economic zone extends to 200 nautical miles from the baselines from which the breadth of the territorial sea is measured.

6. Thus the "Ocean Ranger", owned by ODECO International Corporation of New Orleans, was flying the United States flag.

7. See, e.g., Swan, "The Newfoundland Offshore Claims: Interface of Constitutional Federalism and International Law" (1976) 22 McGill L.J. 541; Douglas, "Conflicting Claims to Oil and Natural Gas Resources off the Eastern Coast of Canada" (1980) 18 Alta. L. Rev. 54. 
Under the present state of international, ${ }^{8}$ Canadian ${ }^{9}$ and United States law ${ }^{10}$, semi-submersible rigs operating in the Hibernia area would be regarded as vessels on the High Seas. Such rigs are therefore subject in part to federal legislative power over "Navigation and Shipping"." There is, however, no conflicting paramount federal legislation in the area of Workers' Compensation. ${ }^{12}$

Responsibility for marine safety on the High Seas is determined by international agreements. The 1958 Convention on the High Seas ${ }^{13}$ states in Article 10:

1. Every state shall take such measures for ships under its flag as are necessary to ensure safety at sea with regard inter alia to:

(a) The use of signals, the maintenance of communication and the prevention of collisions;

(b) The manning of ships and labour conditions for areas taking into account the applicable labour instruments;

(c) The construction, equipment, and seaworthiness of ships;

2. In taking such measures each State is required to conform to generally accepted international standards and to take any steps which may be necessary to ensure their obseryance.

It is also very interesting to note the detailed provisions concerning this area contained in the Convention on the Law of the Seas of the Third U.N. Conference on the Law of the Sea. ${ }^{14}$ The following provisions of Article 94 were adopted by the international community without modification:

\section{Article 94 \\ Duties of the Flag State}

1. Every State shall effectively exercise its jurisdiction and control in administrative, technical and social matters over ships flying its flag.

8. It is difficult to imagine international law characterising the submersible and semisubmersible offshore rigs other than as vessels. Many of the international agreements on the Law of the Sea refer to apparatus for drilling in the offshore as "installations" or "structures" or even as "artificial islands". See, e.g., U.N. Geneva Convention on the Continental Shelf, U.N. Doc. A/Conf. 13 L. 55, Art. 5(4); U.N. Third Conference on the Law of the Sea, Draft Convention on the Law of the Sea, Articles 56 and 60 (recently passed by the General Assembly). Does, however, terminology such as "artificial islands" or "installations" or "structures" preclude these offshore rigs being characterised as ships? The Geneva Convention on the Continental Shelf states that these "installations" or "structures" could not have the status of islands, even if affixed to the seabed; Article 5(4). For United States law concerning offshore oil rigs and platforms affixed to the ocean floor, see $n .78$ infra and accompanying text.

9. Fort William v. MacNamara (1957) 10 D.L.R. (2d) 625 (Ont. H.C.); Seafarers International Union v. Crosbie Offshore Services Ltd. (1982) Federal Court of Appeal Action No. A-2.81 at 13. See contra, Dome Petroleum Ltd. v. N. Bunker Hunt [1978] 1 F.C. 11 (F.C.T.D.), where Dube, J. held that with reference to the definition of a ship in the Canada Shipping Act, R.S.C. 1970, c. S.9 as am., that if drilling ships were not "navigating" when drilling through land, they were not ships. This decision has been severely criticized. See Spicer, "Some Admiralty Issues in Offshore Oil and Gas Development" (1982) 20 Alta. L. Rev. 153 at 157-60.

10. Hicks v. ODECO(1975) 512 F. $2 \mathrm{~d} 817$ (U.S.C.A., 5th Cir.).

11. Constitution Act 1867, as am., s. 91(10).

12. See $\mathrm{n} .35$ infra and accompanying text. The offshore rigs may be governed for general regulatory purposes by the Canada Shipping Act, R.S.C. 1970, c. S-9, but such federal legislation does not cover legislative authority concerning workers' compensation.

13. U.N. Doc. A/Conf. 131/53 signed by Canada April 29, 1958.

14. U.N. Doc. A/Conf. 62/WP, 10/Rev. 3, 27 August 1980, Geneva, 28 July - 29 August 1980. The Convention was passed with amendments relating to deep-sea mining by the General Assembly of the U.N. by a vote of $130^{\circ}$ to 4 with 17 abstentions and has been signed by 119 states, including Canada. However, the validity of the treaty is seriously in doubt, as the U.S. voted against the package and Britain, Belgium, the Netherlands, Italy, West Germany and the Soviet Union, among others, abstained. See Associated Press report in the Edmonton Journal, May 1, 1982, p. A12. 
2. In particular every State shall:

(a) Maintain a register of shipping containing the names and particulars of ships flying its flag, except those which are excluded from generally accepted international regulations on account of their small size; and

(b) Assume jurisdiction under its internal law over each ship flying its flag and its master, officers and crew in respect of administrative, technical and social matters concerning the ship.

3. Every State shall take such measures for ships flying its flag as are necessary to ensure safety at sea with regard, inter alia, to:

(a) The construction, equipment and seaworthiness of ships;

(b) The manning of ships, labour conditions and the training of crews, taking into account the applicable international instruments;

(c) The use of signals, the maintenance of communications and the prevention of collisions.

4. Such measures shall include those necessary to ensure:

(a) That each ship, before registration and thereafter at appropriate intervals, is surveyed by a qualified surveyor of ships, and has on board such charts, nautical publications and navigational equipment and instruments as are appropriate for the safe navigation of the ship;

(b) That each ship is in the charge of a master and officers who possess appropriate qualifications, in particular in seamanship, navigation, communications and marine engineering, and that the crew is appropriate in qualifications and numbers for the type, size, machinery and equipment of the ship;

(c) That the master, officers and, to the extent appropriate, the crew are fully conversant with and required to observe the applicable international regulations concerning the safety of life at sea, the prevention of collisions, the prevention, reduction and control of marine pollution, and the maintenance of communications by radio.

5. In taking the measures called for in paragraphs 3 and 4 each State is required to conform to generally accepted international regulations, procedures and practices and to take any steps which may be necessary to secure their observance.

6. A state which has clear grounds to believe that proper jurisdiction and control with respect to a ship have not been exercised may report the facts to the flag State. Upon receiving such a report, the flag State shall investigate the matter and, if appropriate, take any action necessary to remedy the situation.

7. Each State shall cause an inquiry to be held by or before a suitably qualified person or persons into every marine casualty or incident of navigation on the high seas involving a ship flying its flag and causing loss of life or serious injury to nationals of another State or serious damage to shipping or installations of another State or in the marine environment. The flag State and the other State shall co-operate in the conduct of any inquiry held by that other State into any such marine casualty or incident of navigation.

Responsibility for marine safety on offshore rigs operating on the High Seas therefore seems to lie with the authorities of the country whose flag the rig is flying. As the "Ocean Ranger" rig was flying the U.S. flag, the U.S. Coast Guard and the U.S. Bureau of Shipping would have had the responsibility for maritime safety inspection of that rig. ${ }^{15}$

In view of the plethora of possible legal regimes applicable to an offshore area such as Hibernia, the questions addressed here are as follows:

1. In the event of a disaster or accident occurring in an offshore area such as Hibernia and resulting in injury or death to workers resident in Newfoundland or engaged in Newfoundland and employed by the various employers involved in the exploration activities, would Newfoundland's Workers' Compensation legislation prevent injured workers or the dependents of deceased workers from suing their employers or other parties in Newfoundland?

2. If Newfoundland's Workers' Compensation legislation cannot be applied to the offshore, what are the conflict of laws rules governing actions against employers in Newfoundland and other provinces initiated by offshore workers engaged in or resident in Newfoundland or by the

15. Financial Post, February 27, 1982, p. 6. 
dependents of deceased workers who were resident in Newfoundland at the time of the disaster or accident?

3. If Newfoundland's Workers' Compensation legislation cannot be applied to the offshore, what rules govern actions taken in the United States against American-based employer companies, or against the American parents of Canadian employer companies, by offshore workers engaged or resident in Newfoundland or by the dependents of deceased workers who were resident in Newfoundland at the time of the disaster or accident? ${ }^{16}$

\section{CONSTITUTIONAL ISSUES ARISING IN THE OFFSHORE: THE LONG ARM OF NEWFOUNDLAND'S WORKERS' COMPENSATION LEGISLATION}

Turning to the issues raised by the first question, the Workers' Compensation Board of Newfoundland has asserted ${ }^{17}$ that its legislation does extend to the offshore, even if this means that the legislation would extend to cover injuries and deaths on rigs operating on the High Seas. The Board has claimed that the legislation could be applicable to the disaster which sent 84 men to their death when the "Ocean Ranger" semi-submersible drilling platform disappeared in the High Seas 175 nautical miles east of St. John's on February 15, 1982. If the Board's assertion is upheld by the courts, the dependants of deceased workers who were resident in Newfoundland at the time of the Ocean Ranger disaster would be precluded from initiating court actions in Newfoundland against the workers' employers. Moreover, the Board has asserted ${ }^{18}$ that the dependents of deceased workers would by the terms of the Newfoundland Act also be precluded from suing "third party employers" coming within the scope of the Act, that is, employers involved in the "Ocean Ranger" drilling activity other than the rig-operator or rig-owner itself. The Board has stated that all but two employers involved in the "Ocean Ranger's" activities fall within the scope of the Act. ${ }^{19}$ Under this interpretation the employers involved in the "Ocean Ranger" drilling would seem to enjoy almost complete immunity from suits brought in Newfoundland by dependents of workers killed in the disaster.

It is not obvious, however, that the Newfoundland Workers' Compensation Act indeed applies to offshore areas like Hibernia. It is necessary to consider the objection of extraterritoriality as it is raised by both general constitutional considerations and the express jurisdictional limitations contained in the Newfoundland Act.

The power to legislate a statutory Workers' Compensation scheme is derived from Section 92(13) of the Constitution Act 1867 (formerly the British North America Act 1867), which grants to the provinces the right

16. The discussion of this issue will only focus on actions permitted by statutes in the United States. Of the major employers involved in East Coast offshore exploration, Mobil Oil Canada and ODECO Drilling of Canada Ltd. have parent companies located in the U.S.

17. Statement of official of the Newfoundland Workers' Compensation Board in an inter-. view conducted by the writer on April 16, 1982.

18. Id. See also Financial Post, February 27, 1982, p. 6.

19. Id. 
to legislate in regard to "Property and Civil Rights in the Province". ${ }^{20}$ The words "in the Province" appear to impose an express territorial limitation on the right to enact statutory Workers' Compensation schemes. The Newfoundland Workers' Compensation Board, however, could assert its right to extend the legislation to the offshore, without arguing that the territory of Newfoundland extends to the offshore, on the basis of a 1920 Privy Council decision. In Workmen's Compensation Board v. Canadian Pacific Railway Company, ${ }^{21}$ the respondent company was incorporated by Dominion statute and owned a steamship which sank with all its crew in waters outside Dominion territory on a return journey from Skagway, Alaska to Vancouver, British Columbia. Under the British Columbia Workmen's Compensation Act, compensation was payable by the appellant Board to the dependents of lost crewmen who had been employed while resident in the province by the respondent company, whether such dependents were resident in the province or not. The respondent company contributed to the accident fund established by the provincial legislation to cover its employees who came within the scope of the Act. The members of the crew who were lost had been engaged within the province to do work and perform services which in part had to be done or performed within the province. Counsel for the respondent company argued that the British Columbia legislation could not deal with or derogate from civil rights arising outside the province of British Columbia. The respondent company sought an injunction restraining the appellant Board from paying compensation from the provincial accident fund to the dependents of the lost crew. The trial judge and the British Columbia Court of Appeal agreed with the arguments of counsel for the respondent company and enjoined the Board from paying compensation from the provincial accident fund.

The Privy Council reversed the judgment of the Court of Appeal. Viscount Haldane held, inter alia, ${ }^{22}$ that the legislation was intra vires the province even though it purported to cover accidents outside the province. The right to compensation arising under the provincial legislation was a statutory condition of the contract made in the province with a worker resident in the province. Therefore, the Privy Council held that the right to compensation arose not out of tort but out of the workmen's statutory contractual right, which the Privy Council held to be enacted pursuant to a legitimate provincial legislative object. Therefore, the compensation right was not one interfering with rights outside the province. The object of the legislation was in pith and substance the setting up of a scheme for securing a civil right to compensation within the province, even though it attempted to cover injuries or deaths occurring outside the province, and even though general regulation of the industry covered by the compensation legislation came under the federal "Navigation and Shipping" legislative power.

20. Canadian Southern Ry. Co. v. Jackson (1890) 17 S.C.R. 316; McColl v. Canadian Pacific Ry. Co. (1922) 69 D.L.R. 593 (P.C.); Sincennes-McNaughton Lines Ltd. v. Bruneau [1924] S.C.R. 168.

21. [1920] A.C. 184.

22. The Privy Council also held that legislative competence over workers' compensation is not curtailed merely because the company involved was a Dominion company or had its headquarters outside the province, or because the industry covered by the provincial legislation was regulated for other purposes by federal legislative powers such as "Navigation and Shipping". 
While the Privy Council decision has relevance for the extra-territorial application of the Newfoundland Workers' Compensation legislation to the offshore, the decision may be inapplicable to the offshore exploration areas due to the operation of certain provisions of the Newfoundland legislation.

Section 10 of the Newfoundland legislation ${ }^{23}$ deals with accidents occurring while a worker is employed out of the province. Section 10(4) states that:

Subject to this section, compensation is not payable under this part where an accident to a workman happens while he is employed out of Newfoundland.

The effect of this subsection depends upon two points of interpretation. First, what does "out of Newfoundland" mean? Other articles in this volume deal with this issue in detail, but the basic argument against application of the Act to workers in the Hibernia field may be put as follows: the words "out of Newfoundland" amount to a strict territorial limitation ${ }^{24}$ upon the application of the Act; it cannot be applicable to an offshore area like the Hibernia field because in such a case the sole purpose of the worker's employment is to work on offshore rigs situated outside the boundaries of Newfoundland, and even outside the territorial seas of Canada.

Where the boundaries of Newfoundland fall for the purpose of legislating "in the Province" is, of course, the question presently pending before the Supreme Court of Canada. The famous English case of $R$. v. Keyn $n^{25}$ held that the territory of England ended at the low mater mark. This case was affirmed by the Supreme Court of Canada in Re Offshore Mineral Rights of British Columbia ${ }^{26}$, in which the Court held that the territory of British Columbia ended at the low water mark in the absence of legislation by the competent legislature either before or after Confederation. The Govern-

23. Workers' Compensation Act, R.S.N. 1970, c. 403 as am., S.N. 1979, No. 43, s. 1. Subsections (1) to (3) presently read:

(1) Where the usual place of employment of a worker is in the province and is in an industry coming under this Part and an accident happens while the worker is employed out of the province, the worker or his dependents are entitled to compensation in the same manner as if the accident had happened in the province, unless the worker or his dependents are entitled to compensation under the law of the place where the accident happens.

(2) In any case where compensation is payable in respect of an accident happening out of Newfoundland, if the employer has not fully reported to the Board all the wages of the worker to whom the accident has happened, he is, except insofar as he may be relieved by the Board, liable for the full amount or capitalized value of the compensation and the payment of that amount may be enforced in the same manner as the payment of an assessment may be enforced.

(3) The Board may make or carry out arrangements with the Workers' Compensation Board of any other province to avoid duplication of assessment on the earnings of workers protected at the same time under the laws of two or more provinces relating to workers' compensation and may make any adjustment in assessments by the employers of the workers that the Board deems equitable and may repay any other Workers' Compensation Board for any payment of compensation made by it under any of those arrangements.

24. The crucial question then becomes, how wide is the scope of such a limitation? Does it apply to all accidents and deaths occurring outside Newfoundland, or only to those occurring in industries or employment being in their essence beyond the territory of Newfoundland?

25. (1876) 2 Ex. D. 63 (P.C.).

26. (1967) 65 D.L.R. (2d) 353 (S.C.C.). 
ment of Newfoundland claims that these English and British Columbia precedents have no relevance to Newfoundland which had pre-Confederation sovereign rights ${ }^{27}$ in the territorial sea and minerals in the continental shelf, which rights were preserved by the 1949 Terms of Union of Newfoundland with Canada. ${ }^{28}$

Even if the arguments of the Government of Newfoundland are accepted by the Supreme Court of Canada, it is not clear whether rights to minerals in the continental shelf of the coast of Newfoundland would permit the high seas above the continental shelf to be regarded as the territory of Newfoundland for the purposes of the Newfoundland Worker's Compensation Act. It could be argued in favour of this interpretation that it is absurd to give Newfoundland the legal right to minerals in the continental shelf and the right to exploit those resources but then to assert that Newfoundland should not have general regulatory authority, including Workers' Compensation jurisdiction, over the oil rigs which are there to locate and exploit the mineral resources. Such regulatory powers must be necessarily incidental to the power to exploit any minerals which may belong to the province of Newfoundland.

If the claims of the Newfoundland government to the offshore are rejected, and Section 10(4) of the Act therefore limits the operation of relevant parts of the Act to the land territory of Newfoundland, the case for extending coverage under the legislation to individuals employed in areas such as Hibernia becomes more tenuous. In such a case the second point of interpretation, the meaning of the word "employed" in Section 10(4), becomes crucial. The Newfoundland government and its Workers' Compensation Board could argue that the word "employed" in Section 10(4) of the Act refers not to where the worker was physically present at the time of the accident, but to the "usual place of employment". ${ }^{29}$ If this wider interpretation of "employed" is used in applying the restriction on jurisdiction contained in Section 10(4), the geographical classification of the Hibernia field as being "in" or "out of" Newfoundland becomes irrelevant so long as the usual place of employment of the worker was Newfoundland. While this concept has not been defined by the Newfoundland legislation, it could be argued that in the absence of any alternative credible location, the usual place of employment of most of the workers on the oil rigs in the offshore is Newfoundland. ${ }^{30}$ An analogy could be drawn from the other main offshore industry, the fishing industry, where the usual place of employment is deemed to be the home port of the employment. ${ }^{31}$ Professor Ison has argued that in deciding with which legislative jurisdiction the employment of the offshore workers has the most substantial connection,

27. See Swan, supra n. 7; Martin, "Newfoundland's Case on Offshore Minerals: A Brief Outline" (1975) 7 Ottawa L. Rev. 34.

28. Schedule of Terms of Union of Newfoundland with Canada, Newfoundland Act (formerly British North America Act 1949), 12 \& 13 Geo. 6, c. 22; R.S.N. 1970, Appendix, no. 5 .

29. See Section 10(1), supra note 23.

30. For Professor Ison's view of how this term should be interpreted in the context of offshore employment, see $\mathrm{n} .32$ infra and accompanying text.

31. It has not been suggested that applying Newfoundland Workers' Compensation legislation to injuries or deaths of fishermen while on the high seas is unconstitutional. See Bonavista Cold Storage Co. Ltd. v. Walters (1959) 20 D.L.R. (2d) 744. 
the following factors might be considered $:^{32}$

(1) At what place did the workers come under the orders of their employers, and at what place were they released from those orders at the beginning and end of each period of duty? In this connection, where did each worker report for the transportation provided by the employer to the rig, and what was the place of disembarkation from that transportation on the return? With regard to those hired outside Newfoundland, did they travel by public transport to the province or in special transport arranged by the employer?

(2) Was there any other place that could reasonably be called the home base of the employment?

(3) Was the worker employed to work on the rig in that field or had he contracted as a crewman to go with the rig to wherever it might move?

(4) What was the base for supplies and provisioning of the rig?

(5) Which nation, if any, accepted protective responsibility in the event of rescue being required?

(6) Were the workers treated as subject to Canadian law for other purposes, such as unemployment insurance, Canada Pension Plan, and income tax?

(7) Where was the office responsible for hiring; and for the ongoing employment relationship?

(8) Where was the payroll administered?

(9) If any of the workers on the rig were organized for collective bargaining, where did the bargaining take place?

(10) What was the place of medical attention or other services in the event of injury?

Applying these factors to the workers employed on the rigs in the offshore area, it is likely that the "usual place of employment" will he deemed to be the province of Newfoundland..$^{33}$

As stated before, the Newfoundland Workers' Compensation Board has decided that employment on the offshore rigs is within the compulsory coverage provisions of Part 1 of the Act. Once an industry or employment comes within the provisions of Part 1 of the Act, an injury or death

32. Legal Opinion of Professor Terence G. Ison on the Ocean Ranger Disaster (April 1982, unpublished).

33. Id. Professor Ison is of the view that the first factor is the most important one. Most of the employees on the offshore rigs, even those who are not residents of Newfoundland, get to the offshore rigs in the Hibernia field via helicopter or boat from Newfoundland. Thus the first factor seems to be a strong indication that Newfoundland is the "usual place of employment" of most of the offshore workers. 
accidentally arising in the course of the worker's employment is subject to the statutory compensation scheme of the Act. It is submitted that nothing either express or implied in Section 10 or any other section of the Act requires that the death or injury should occur within the province of Newfoundland. The Act only requires that the industry or employment in which the injured or deceased worker was ordinarily engaged comes within the provisions of Part 1 of the Act.

On the balance of probabilities, it is likely that the courts would find that the 1920 Privy Council decision of Workmen's Compensation Board v. C.P.R. would allow Newfoundland to extend its Workers' Compensation legislation to the offshore and that Section 10(4) of the Act would not be an impediment to such a finding. The policy reasons why the courts should so decide are overwhelming. If Newfoundland could not extend its Workers' Compensation legislation to the offshore, especially to cover those workers resident in, hired in, and working from a base in Newfoundland, what other jurisdiction could present a credible claim to be the main place of employment of such workers?

There is little doubt that the Parliament of Canada could pass accident compensation legislation that has extra-territorial application in international waters. The federal Merchant Seamen Compensation Act expressly applies to accidents happening within or outside Canada ${ }^{34}$ to seamen on ships registered in Canada. In certain circumstances it also applies to a ship registered outside of Canada but chartered to a person resident in Canada or having his principal place of business in Canada. ${ }^{35}$ The applicability of the Act, however, depends on proving that the ship was engaged in trading on a foreign or home-trade voyage. ${ }^{36}$ While the Merchant Seamen Compensation Act allows provincial workers' compensation legislation to prevail ${ }^{37}$ where such legislation grants compensation to seamen or their dependents, it would not prevent an injured seaman or his dependents from going to court and asserting that such provincial legislation is ultra vires if it purports to apply beyond provincial boundaries.

The substance of the argument that Newfoundland cannot extend its Workers' Compensation legislation to the offshore area is that to decide otherwise would be to allow Newfoundland to legislate extra-territorially; the Newfoundland legislation is not in pith and substance the enforcement of a civil right within that province, but rather an attempt to curtail civil rights arising from negligent acts occurring not only outside the boundaries of the province of Newfoundland, but as regards areas like the Hibernia field, outside the territorial seas of Canada. It could also be argued that the 1920 Privy Council decision in Workmen's Compensation Board v. C.P.R. ${ }^{38}$ was either wrongly decided or distinguishable, and that

34. R.S.C. 1970, c. M-11, s. 6, which states: "This Act applies to accidents happening within or outside Canada."

35. Id., s. 2.

36. Id. Therefore it is unlikely that the Act applies to workers on the offshore rigs.

37. Id., s. 4, which states:

No compensation is payable under this Act

(a) where a seaman or his dependants are entitled to claim compensation under the Government Employees Compensation Act or under any provincial workers' compensation law...

38. Supran. 21. 
more recent Supreme Court of Canada decisions would seem to be in conflict with that case. ${ }^{39}$

It is suggested that these arguments would, for the policy reasons discussed above, not be sufficient to prevent the courts from permitting Newfoundland to extend its legislation to the offshore, at least insofar as such legislation covers residents of Newfoundland working on the offshore oil rigs.

\section{CONFLICT OF LAWS ISSUES IN THE OFFSHORE:}

\section{A LEGAL "CATCH-22"}

For the purposes of this part of the discussion, it will be assumed that the setting up of a workers' compensation scheme for employment on the offshore rigs is beyond the constitutional capacity of the Government of Newfoundland, and that offshore areas such as Hibernia are outside the jurisdiction of the province. If Newfoundland's Workers' Compensation legislation cannot be applied to the offshore, what are the common law conflict of laws rules governing actions against employers in Newfoundland and other provinces?

Actions initiated by injured workers would probably assert negligence on the part of the employers. Actions initiated by the dependents of deceased workers would, of course, be based on Newfoundland's Fatal Accidents Act. ${ }^{40}$ As most of the employers involved in the offshore exploration activity have local bases of operation in Newfoundland, such employers or their agents could be personally served with process, so as to allow the Newfoundland courts to assume jurisdiction. The Newfoundland courts would probably regard themselves as an appropriate or convenient forum to hear the personal injury or fatal accident litigation. ${ }^{41}$ However, to the relief of many offshore employers, the outcome of such litigation would not be the payment of hundreds of thousands or perhaps millions of dollars in damages as a result of "Ocean Ranger"-type disasters, even if negligence on the part of the employers could be proved..$^{42}$ This is due to the workings of the peculiar conflict of laws rules concerning actions that allege wrongful acts committed outside the forum jurisdiction.

In such an action, the court must first select the law which will determine the rights and liabilities of the parties. The conflict of laws rules which Canadian courts apply to determine the choice of law was first formulated in the 1870 English case of Phillips v. Eyre,$^{43}$ which held that as a general rule, in order to found a suit in England for a wrong alleged to have been committed abroad, two conditions must be fulfilled:

39. Burns Foods Ltd. v. Attorney-General of Manitoba [1975] 1 S.C.R. 494; Interprovincial Co-operatives Ltd. v. The Queen [1976] i S.C.R. 477.

40. R.S.N. 1970 , c. 126, as am.

41. For a general discussion of the complex conflicts of law doctrine of forum conveniens, see Castel, "Jurisdiction and the Exercise of Discretion by the Court - Forum Conveniens" (1971) 49 Can. Bar Rev. 466; McClean, "Jurisdiction and Judicial Discretion" (1969) 18 Int. and Comp. L.Q. 931; Antares Shipping Corp. v. The "Capricorn" (1976)65 D.L.R. (3d) 105 (S.C.C.).

42. A widow is asking in a U.S. District Court for $\$ 314$ million in damages for the death of her husband in the "Ocean Ranger" disaster. Another widow of an "Ocean Ranger" worker is asking for $\$ 2$ million in damages in the U.S. courts. Edmonton Journal, March 20, 1982, p. A10.

43. (1870) L.R. 6 Q.B. 1, 40 L.J.Q.B. 28. 
First, the wrong must be of such a character that it would be actionable if committed in England.

... Secondly, the act must not have been justifiable by the law of the place where it was done. ${ }^{4}$

If both conditions of the Phillips v. Eyre rule are satisfied, then the English courts determine the heads and measure of damages according to the rules of the forum. ${ }^{45}$ If not, the action will be dismissed. The Supreme Court of Canada has followed and applied the Phillips v. Eyre rule in Canada. ${ }^{46}$

Under the first condition in the Phillips v. Eyre rule, the plaintiff must prove that had the defendant's act been committed within the forum, it would have been an actionable wrong under the rules of the forum. ${ }^{47}$ The second condition of the rule has been interpreted by English and Canadian courts to mean that the alleged wrongful conduct will only be justified in the place where it was committed if that conduct was "innocent", or was not "wrongful", or did not give rise to the possibility of civil or criminal liability. ${ }^{48}$ As regards locating the place where the tort was committed for the purposes of the second condition in Phillips v. Eyre, there is an increasing tendency by the courts to locate the tort where the harm was suffered, especially in the case of defective products. ${ }^{49}$

Applying the Phillips v. Eyre rule to determine liability for wrongful conduct occurring in offshore exploration areas, however, raises the possibility of a legal "Catch-22". The second condition in Phillips v. Eyre would probably be satisfied if injuries or deaths resulted from, for example, breaches of the rules of International Maritime Law as illustrated above or as administered in Canada under the provisions of the Canada

44. Id. at 28-29.

45. Some jurists have asserted that the Phillips v. Eyre conflicts of law rule is only a rule going to jurisdiction, without stipulating what law should apply to foreign tort actions; Spence, "Conflict of Laws in Automobile Negligence Cases" (1949) 27 Can. Bar Rev. 661. However, the cases seem to indicate that it does not matter whether the Phillips v. Eyre rule is a jurisdictional rule or a choice of law rule. If either of the two conditions in the rule is not met, Canadian courts dismiss the action. If the two conditions are met, the courts invariably apply the law of the forum as it applies to heads and measures of damages. Brown v. Poland and Emerson Motors Ltd. [1952] 6 W.W.R. 368 (Alta. S.C.); LaVan v. Danyluk and Danyluk (1970) 75 W.W.R. 500 (B.C.S.C.).

46. O'Connor v. Wray[1930] S.C.R. 231, [1930]2 D.L.R. 899; Canadian National Steamship Co. v. Watson [1939] S.C.R. 11, [1939] 1 D.L.R. 273.

47. This part of the Phillips v. Eyre rule has been criticized as being extremely parochial and chauvinistic, as it makes conflicts of law rules concerning foreign torts no more than an "appendix" to the domestic law of torts. See Willis, "Two Approaches to the Conflict of Laws: A Comparative Study of the English Law and the Restatement of the American Law Institute" (1936) 14 Can. Bar Rev. 1 at 19.

48. The word "justifiable" in the second condition of the Phillips v. Eyre rule has been interpreted to mean "innocent", in that the alleged wrongful conduct is capable of giving rise to neither civil nor criminal liability under the lex loci delicti. See Machado v. Fontes [1897] 2 Q.B. 231, 66 L.J.Q.B. 542 (C.A.). In its proposition that an act is "not justifiable" (and hence actionable civilly) under the Phillips v. Eyre rule if it attracts only criminal liability under the lex loci delicti, Machado v. Fontes has been overruled in England by Boys v. Chaplin [1971] A.C. 356. Machado v. Fontes has, however, been approved and followed by the Supreme Court of Canada in McLean v. Pettigrew [1945]2 D.L.R. 65 .

49. Moran v. Pyle National (Canada) Ltd. [1975] 1 S.C.R. 393, 43 D.L.R. (3d) 239; see also Fridman, "Where is a Tort Committed?" (1974) U. of Toronto L.J. 247; Hurlburt, Comment (1974) 52 Can. Bar Rev. 470. 
Shipping Act $^{50}$ and other federal legislation. The first condition, though, would seem not to be satisfied in such a case because if the wrongful conduct occurring in the offshore exploration areas were to occur within the boundaries of Newfoundland, the provincial Workers' Compensation legislation would preclude such conduct being actionable in a suit by injured workers engaged or resident in Newfoundland or their dependents. ${ }^{51}$ Their only right would be a statutory right to compensation from the accident fund set up by the Act. Both conditions of the Phillips v. Eyre rule not being satisfied, an action brought by injured workers or the dependents of deceased workers for wrongful conduct committed on the

50. Simonson v. Canadian Northern Ry. Co. (1914) 17 D.L.R. 516 (Man. C.A.); Jones v. Canadian Pacific Ry. Co. (1919) 49 D.L.R. 335 (Man. C.A.). Note, however, that provisions in one provincial Workers' Compensation Act cannot prohibit actions being brought in another province. Thus, in Desharnais v. Canadian Pacific Ry. [1942] 4 D.L.R. 605 (Sask. C.A.), the court held that the Alberta Workmen's Compensation Act was ultra vires that province insofar as it purported to deprive employees who were residents of Alberta, injured in the course of employment in Saskatchewan, the right of action against their employers given them by the Saskatchewan Workmen's Compensation Act, R.S.S. 1940, c. 302. The court also held that it would not matter if their contracts of employment were made in Alberta and that such contracts incorporated the provisions of the Alberta Workmen's Compensation Act.

Section 12(1) of the Newfoundland Workers' Compensation Act precludes actions against employees covered by Part 1 of the Act:

12. (1) Subject to subsection (2) of this section, in any case referred to in subsection (1) of Section 11, neither the worker, his personal representative, his dependents nor the employer of the worker has any right of action in respect of the accident against an employer in any industry within the scope of this Part or against any worker of that employer unless the accident occurred otherwise than in the conduct of the operations usual in or incidental to the industry carried on by the employer; and in any such case where it appears to the satisfaction of the Board that a worker of an employer in any class is injured or killed owing to the negligence of an employer or of the worker of an employer in any other class within the scope of this Part, the Board may direct that the compensation awarded in that case shall be charged against the last-mentioned class.

51. For an interesting judicial analysis of how the Phillips v. Eyre rule applies to maritime torts and the interaction between the relevant provisions of the Canada Shipping Act, R.S.C. 1970, c. S-9, as am., in particular the conflict of laws provisions in 8.274 and the total accidents provision in $\mathrm{s} .716$, relevant provisions in provincial compensation legislation and the Phillips v. Eyre rule, see the British Columbia Court of Appeal judgment in Grondlund v. Hansen (1969) 4 D.L.R. (3d) 435.

There is a possible argument to be made that the statutory conflict of laws rule in Section 274 of the Canada Shipping Act which makes the application of the law of the vessel's registry mandatory where a conflict of laws situation exists, renders the Phillips v. Eyre rule irrelevant to the case of maritime torts. However, in the Grondlund v. Hansen decision, the British Columbia Court of Appeal, using the Supreme Court of Canada decision in C.N.R. v. Watson [1939] 1 D.L.R. 273 as authority, seems to imply that the conflict of laws provision in section 274 of the Canada Shipping Act is only relevant in determining whether the maritime tort is "justifiable" under the laws of the place where the tort was committed and that s. 274 of the Canada Shipping Act is only applicable if the second rule in the Phillips v. Eyre rule cannot resolve the question of "justification" for a maritime tort: supra at 441-444.

A difficult problem arising in the aftermath of offshore rig accidents is to ascertain exactly whose conduct was wrongful, i.e. not "innocent", in the matter. The rig-owner or rig-operator could be responsible for the provision of adequate safety equipment such as life boats. If the rig sank due to a faulty structural design, the above two parties, plus builders of the rigs such as Mitsubishi Heavy Industries Ltd. of Japan could be the parties at fault. Finally, failure to provide adequate maritime safety inspection of the offshore rigs could result in the U.S. Government, the U.S. Coast Guard or the U.S. Bureau of Shipping being parties whose conduct is "wrongful". The possibility of plaintiffs going "defendant-shopping" clearly exists! 
High Seas outside the territory of Newfoundland would have to be dismissed.

This legal "Catch-22" that litigants may find themselves in could only be broken in a jurisdiction that does not adhere to the Phillips v. Eyre conflict of laws rule and does not have Workers' Compensation legislation containing a statutory bar to actions similar to the one in the Newfoundland legislation. As most of the common law provinces of Canada have both the Phillips v. Eyre rule in their common law and statutory bars to action in the provincial Workers' Compensation acts ${ }^{52}$, the first condition of the Phillips v. Eyre rule could not be satisfied anywhere in Canada, even if the courts of another province were to accept jurisdiction to hear personal injury or fatal accident claims arising from events in the offshore areas.

If the application of Workers' Compensation legislation is intra vires the province of Newfoundland, it seems clear that injured workers or the dependents of deceased workers could not sue their employers in the courts of other common law provinces. Such actions would have to be dismissed, again because the two conditions of the Phillips v. Eyre rule would not be satisfied. It is submitted that Canadian courts would hold Newfoundland's Workers' Compensation legislation to be the lex loci delicti once they decided the preliminary issue that its application to the offshore was intra vires the province of Newfoundland. The first condition of the Phillips v. Eyre rule would not be satisfied, for the same reasons as advanced above. Neither would the second condition of the rule be satisfied, for the existence of Newfoundland's statutory bar to actions against employers covered by the legislation would make any tortious conduct by employers concerning the offshore rigs and resulting in death or injury "justifiable" under the law of the place where the tort is committed, unless the act gives rise to a separate criminal liability. ${ }^{53}$

Thus, however the constitutional issue is resolved, tort claims by injured workers or the dependents of deceased workers would be totally frustrated by a common law conflict of laws rule originating in an 1870 English case. Never in his wildest dreams would Willes J., who formulated the Phillips v. Eyre rule, have thought his conflict of laws rule could apply in the late twentieth century to accidents and disasters on monstrous structures sitting in the middle of the ocean and drilling in the continental

52. Section 16(1) of the Alberta Workers' Compensation Act, for example, precludes actions against employers covered by the Act:

16 (1) No action lies for the recovery of compensation under this Act and all claims for compensation shall be determined by the Board.

(2) This Act and the regulations apply in lieu of all rights and causes of action, statutory or otherwise, to which a worker, his legal personal representatives or his dependents are or might become entitled against the employer of the worker by reason of any accident happening to the worker, and no action in respect of that accident lies against the employer.

(3) Any party to an action may, on notice to the other parties, apply to the Board for determination of whether a worker who is a party to the action is entitled to compensation under this Act and the Regulations.

53. See n. 48 supra. Precisely this resulted from the peculiar relationship between the rule in Phillips v. Eyre and provincial workers' compensation legislation in the two famous cases of Walpole v. Canadian Northern Ry. Co. [1923] A.C. 113, (1922) 70 D.L.R. 201; and McMillan v. Canadian Northern Ry Co. [1923] A.C. 120, (1922) 70 D.L.R. 229. The law of the vessel's registry could also be the lex loci delicti under the conflict of laws provisions of Section 274 of the Canada Shipping Act. See also n. 51, supra. 
shelf to locate vast hydrocarbon resources. ${ }^{54}$

\section{BREAKING OUT OF THE LEGAL "CATCH-22": SHOPPING FOR A U.S. FORUM}

If injured workers who were engaged or resident in Newfoundland or dependents of such workers are unable to sue their employers in any Canadian jurisdiction, they may settle for the statutory compensation available under the Newfoundland Workers' Compensation Act. If they feel much more than this is due to them, they may attempt to pursue their tort claims in a foreign jurisdiction. They may turn to the possibility of initiating tort and statutory actions in a jurisdiction in the United States where the parent companies of some of the Canadian subsidiaries involved in offshore exploration have their headquarters. ${ }^{55}$

The factors that the United States courts would take into account in deciding whether to accept jurisdiction are as follows: ${ }^{56}$

(1) The place of the wrongful act. Most of the areas where offshore exploration activity is centered would be regarded as the High Seas. U.S. admiralty jurisdiction extends to the High Seas.

(2) The law of the flag that the rig was flying. As most of the owners of these rigs are U.S. corporations, the rigs would be flying the U.S. flag.

(3) The allegiance or domicile of injured or deceased parties. In most cases, the offshore workers would be domiciled in Newfoundland or some other province of Canada. Thus, allegiance would be owed to Canada. However, huge operations like offshore exploration activity inevitably draw workers of many nationalities who provide specialized services.

(4) The allegiance of the vessel owner. As discussed above, in most cases the vessel owner would be a U.S. corporation and so would owe allegiance to the United States.

(5) The place of the contract. For a majority of offshore workers in areas such as Hibernia, the place of the employment contract

54. Some jurists have commented that it is time Anglo.Canadian jurisprudence abandoned the Phillips v. Eyre conflict of laws rule and adopted the American "proper law of the tort" approach, in which the U.S. courts apply to foreign torts the law of the jurisdiction which has the most significant connection with an interest in the alleged wrongful conduct. See Morris, "The Proper Law of Tort" (1951)64 Harv. L. Rev. 881; Shapira, "A Transatlantic Inspiration: The Case For and an Outline of a New Approach" (1967) 3 U.B.C. Law Rev. 185. See also the judicial attempts to adopt a new approach in Canada in Grondlund v. Hansen (1968) 69 D.L.R. (2d) 598 (B.C.Co.Ct.) and La Van v. Danyluk and Danyluk (1970) 75 W.W.R. 500 (B.C.S.C.).

55. Supra n. 44. Most of the dependents of the workers who died in the "Ocean Ranger" disaster will probably sue in the U.S. District Court of Louisiana, where ODECO International Corporation has its headquarters. If there are sufficient contacts between the two Canadian companies involved, ODECO Drilling of Canada and Mobil Oil Canada Ltd., and the State of Louisiana, the U.S. District Court in Louisiana could assert jurisdiction to hear claims against the two Canadian companies also.

56. Lauritzen v. Larson (1953) 345 U.S. 571; Hellenic Lines Ltd. v. Rhoditis (1970) 398 U.S. 306; De Alvarez v. Creole Petroleum Corp. (1978) 462 F. Supp. 782; Phillips v. Amoco Trinidad Oil Co. (1980) 632 F. 2d 82 (U.S.C.A., 9th Cir.). 
would probably be Newfoundland. However, those employees providing specialized services could have signed their contracts anywhere in the world.

(6) The inaccessibility of foreign forums. This criterion is likely to provide problems because Newfoundland is an "accessible" alternative forum, at least regarding the rig-operator and contractors, who are likely to have operations and assets in Newfoundland. Even as regards rig-owners such as ODECO International Corporation of Louisiana, leave to serve process on that corporation ex juris could be obtained in Newfoundland. The fact that the rigowners do not carry on business in Newfoundland should not be an insurmountable problem to the Newfoundland courts obtaining jurisdiction over them.

(7) Whether the defendants are doing business in the forum. U.S. companies which own some of the offshore rigs clearly do business in the United States, but it is more difficult to ascertain whether the Canadian employers of offshore workers are "doing business" in the U.S. jurisdiction in which claims would be heard. Should "doing business" be taken to imply a physical presence in the forum, it is clear that the major employers of first instance, offshore exploration companies such as Mobil Oil Canada, Ltd., ODECO Drilling of Canada Ltd., and Petro-Canada, have their bases of operations in Canada rather than in an American jurisdiction. On the other hand, the contract of hire between the rig-owner and the rig-operator may have been executed in a U.S. jurisdiction. Whether the execution of such a contract by a foreign rig-operator would in itself constitute "doing business" in the forum jurisdiction is uncertain. Finally, it may be sufficient to attract jurisdiction that the parent companies of the Canadian employers are doing business in the U.S. jurisdiction where actions are initiated. In the area of accident claims, U.S. courts may be willing to lift the corporate veil to reveal the naked unity between a U.S. parent company and its foreign subsidiary ${ }^{57}$

Applying the above factors, the U.S. Federal District Courts could probably accept jurisdiction to hear the claims of offshore workers resident or engaged in Newfoundland, or the dependents of deceased workers resident or engaged in Newfoundland at the time of the accident. ${ }^{58}$

United States Federal Courts would probably apply U.S. law to such actions if they accepted jurisdiction. The remedies available under U.S. law to the above-mentioned plaintiffs arise mainly from the Jones Act ${ }^{59}$

57. Fitzgerald v. Angela Compania Naviera (1976) 417 F. Supp. 151 (D.C.N.Y.), reversed on other grounds, 592 F. $2 \mathrm{~d}$ 58. Certiorari denied, 100 S. Ct. 15, 443 U.S. 928.

58. Note, however, that the U.S. courts have the power to dismiss claims on the grounds of forum non conveniens. See Yohanes v. Ayers S.S. Co. (1971) 451 F. 2d 349 (U.S.C.A., 5th Cir.); certiorari denied, 92 S. Ct. 1771, 406 U.S. 919; Camarias v. M/V Lady Era(1970) 318 F. Supp. 379 (D.C.Va.), affd. 432 F. 2 d 1234. Generally, see GulfOil Corp. v. Gilbert (1947) 330 U.S. 501; Koster v. Lumbermen's Mutual Casualty Co. (1947) 330 U.S. 518; Piper Aircraft Co. v. Gaynell Reyno et al. (1981) 50 U.S. Law Week 4055.

59. 46 U.S.C., s. 688. 
and the Death on the High Seas Act. ${ }^{60}$ The former Act permits injured seamen who suffer personal injury in the course of employment to maintain an action for damages against the employer and against the vessel owner if the vessel was unseaworthy at the time of the accident. ${ }^{61}$ The Act also allows the personal representatives of deceased seamen to maintain similar actions. ${ }^{62}$ Jurisdiction in such actions lies with the court of the district in which the defendant employer resides or in which his principal office is located. ${ }^{63}$ It is uncertain whether charterers of vessels may also be liable under this section to seamen who are injured or killed due to the negligence of the charter. ${ }^{64}$

Damages recoverable by injured seamen under the Jones Act are assessed commensurate with the nature and extent of injuries, including reimbursement for loss of past and prospective earnings, medical expenses incurred and to be incurred in future, other types of economic loss, and damages for pain, suffering, mental anguish, discomfort and inconvenience. ${ }^{65}$ Damages recoverable by the dependents of deceased seamen include loss of contribution and economic support, ${ }^{66}$ and any other pecuniary benefits, including fringe benefits, that would have resulted had the deceased lived. ${ }^{67}$ Earning capacity is, of course, related to life and work expectancy. ${ }^{68}$ Included in pecuniary losses are loss of companionship and society ${ }^{69}$ loss of nurture, guidance and training as regards the children of the deceased, ${ }^{70}$ and even funeral expenses. ${ }^{71}$ Many U.S. courts have also awarded posthumous damages for pain and suffering where it has been proved that seamen suffered conscious pain before they died. ${ }^{72}$

It should be emphasized that United States courts must first find that the Canadian offshore workers had "seamen's" status and that the offshore rigs can properly be regarded as "vessels". The case law has defined a "seaman" for the purposes of the Jones Act by the following requirements: ${ }^{73}$

(1) The vessel must be in navigation, but not necessarily actually in movement;

(2) The alleged "seaman" must have a more or less permanent connection with the vessel;

60. 46 U.S.C., s. 761.

61. Supra n. 59. Turcich v. Liberty Corp. (1954) 119 F. Supp. 7 (D.C.Va.), affd 217 F. 2d 495, certiorari denied, 76 S. Ct. 470, 350 U.S. 983.

62. Supra n. 59.

63. Id.

64. Viger v. Geophysical Services Inc. (1972) 338 F. Supp. 808 (D.C. La.), affd. 476 F. 2d 1288.

65. Downie v. U.S. Lines Co. (1966) 359 F. 2 d 344 (U.S.C.A., 3rd Cir.), certiorari denied, 87 S. Ct. 201, 385 U.S. 897.

66. Higginbotham v. Mobil Oil Corporation (1973) 360 F. Supp. 1140 (D.C. La.).

67. Mungin v. Calmar S.S. Corp. (1972) 342 F. Supp. 479 (D.C. Md.).

68. Bednar v. U.S. Lines (1973) 360 F. Supp. 1313 (D.C. Ohio).

69. McDonald v. Federal Barge Lines (1979) 496 F. $2 d 1376$ (U.S.C.A., 5th Cir.).

70. Supra n. 68.

71. Cities Service Oil Co. v. Launey (1968) 403 F. 2d 537 (U.S.C.A., 5th Cir.).

72. In re Farrell Lines Inc. (1971) 339 F. Supp. 91 (D.C. La.); Grantham v. Quinn Menhaden Fisheries Inc. (1965) 344 F. 2d 590 (C.A.S.Ca.).

73. Bell v. National Boat Corp. (1979) 298 So. 2d 327 (La. App.). 
(3) The capacity in which the individual is employed or the duties which he performs must contribute to the function of the vessel or to the accomplishment of the mission.

U.S. case law seems to make a distinction between workers employed on fixed offshore oil drilling platforms and those on submersible (and therefore semi-submersible) oil rigs. The courts have held that submersible types of oil rigs are "vessels"74 and that therefore those employed aboard them are classed as "seamen" if they are more or less permanently attached to the rig, their work contributes to the maintenance and safety of the rig while in navigable waters, and their work assists in the accomplishment of the rig's mission, function and purpose, that is, oil exploration. ${ }^{75}$ They have held that, by contrast, offshore oil rigs and platforms fixed to the seabed or ocean floor are not "vessels"76 and that workers who perform all their duties on such platforms are not "seamen" within the provisions of the Jones Act. ${ }^{77}$ The rationale for the distinction between the two structures is that fixed drilling platforms and rigs are incapable of being floated or otherwise moved upon the surface of the water and therefore could not be considered as "vessels in navigation" within the provisions of the Jones Act. ${ }^{78}$ Because submersible and semi-submersible rigs, on the other hand, are capable of being floated and moved from place to place even though they lack self-motive power, they are "vessels". Such rigs while stationary and resting on submerged pontoons and engaged in drilling operations at the time of the accident are still regarded as vessels. ${ }^{79}$

Turning briefly to the Death on the High Seas Act, ${ }^{80}$ the Act permits the spouse, parent, child, or dependent relative of a person who dies due to a wrongful act, neglect or default occurring on the High Seas beyond a marine league (three miles) from the shore of any U.S. state (and even extending into the territorial waters of a foreign country) to bring an action for damages in the U.S. courts. The rationale of the Act is that all persons legitimately on board a vessel, whether "seamen" or not, are entitled to have the vessel owner, operator, contractor, and all other persons on board the vessel exercise reasonable care for their safety. Therefore, under this Act, the dependents of the deceased offshore workers not "seamen" could sue the workers' employers alleging negligence, ${ }^{81}$ or could sue the rig owner alleging unseaworthiness. ${ }^{82}$ Offshore workers who are classified as "seamen" have alternative remedies against their em-

74. Supra n. 10. See also Doucet v. Wheless Drilling Co. (1972) 467 F. 2d 336 (U.S.C.A., 5th Cir.); Rogers v. Gracey-Hellums Corp. (1970) 331 F. Supp. 1287 (D.C. La.), affd. 442 F. $2 d$ 1196; Chenevert v. Clinch Drilling Co. (1967) 273 F. Supp. 943 (D.C. La.).

75. McCarty v. Service Contracting Inc. (1970) 317 F. Supp. 629 (D.C. La.); Robichaux v. Kerr McGee Oil Industries Inc. (1970) 317 F. Supp. 587 (D.C. La.); Fontenot v. Halliburton Co. (1967) 264 F. Supp. 45 (D.C. La.).

76. Johnson v. Noble Drilling Co. (1966) 264 F. Supp. 104 (D.C. La.).

77. Nolan v. Coating Specialists Inc. (1970) 422 F. 2 d 377 (U.S. C.A., 5th Cir.); Thompson v. Crown Petroleum Corp. (1969) 418 F. 2d 239 (U.S.C.A., 5th Cir.); Dronet v. Reading \& Bates Offshore Drilling Co. (1966) 367 F. 2d 150 (U.S.C.A., 5th Cir.).

78. Supra n. 76.

79. Ledet v. U.S. Oil of Louisiana Inc. (1964) 237 F. Supp. 183 (D.C. La.).

80. Supran. 60.

81. Soileau v. Nicklos Drilling Co. (1969) 302 F. Supp. 119 (D.C. La.).

82. Supra n. 67. See also In re Industrial Transp. Corp. (1972) 344 F. Supp. 1311 (D.C.N.Y.). 
ployers under the Jones Act and under the Death on the High Seas Act. ${ }^{83}$ The latter Act, however, provides remedies for additional classes of beneficiaries. ${ }^{84}$ The heads of damage available under the Death on the High Seas Act are essentially the same as those available under the Jones Act. ${ }^{85}$

It is beyond the scope of this article to determine what effect the acceptance of compensation by offshore workers or their dependents under the Newfoundland Workers' Compensation Act would have on their U.S. claims. Generally, the U.S. courts have held that mere acceptance of Workers' Compensation payments under U.S. State law does not bar an action under the two Acts discussed above. ${ }^{86}$

It is also beyond the scope of this article to discuss whether the Newfoundland Workers' Compensation Board could take action in U.S. courts under its statutory right of subrogation against employers covered by the Newfoundland Workers' Compensation legislation and against third parties. The Board would probably have legal standing to sue third parties in the U.S. courts, but it might be presented with greater problems in initiating actions against employers covered by the Newfoundland Workers' Compensation Act. ${ }^{87}$

\section{CONCLUSION}

Although any attempt to draw conclusions from an area as strewn with legal pitfalls as that of tortious liability in the offshore cannot be other than speculative, the foregoing discussion indicates that there is at least some support for the claim that Newfoundland's workers' compensation scheme applies to offshore drilling activities. There is Privy Council precedent for the proposition that such an application of the legislation is not precluded by Section 92(13) of the Constitution Act so long as the employment relationship itself arises "in the Province" of Newfoundland. Neither would the limitation on jurisdiction in Section 10(4) of the New-

83. In re Dearborn Marine Service Inc. (1974) 499 F. 2 d 263 (U.S.C.A., 5th Cir.).

84. Petition of Risdal \& Anderson Inc. (1968) 291 F. Supp. 353 (D.C. Mass.).

85. U.S.C. Section 762 states:

The recovery in such suit shall be a fair and just compensation for the pecuniary loss sustained by the persons for whose benefit the suit is brought and shall be apportioned among them by the court in proportion to the loss they may severally have suffered by reason of the death of a person by whose representative the suit is brought.

For application of such a measure of damages see supra n. 84; The "Black Gull"(1937) 90 F. 2d 619 (U.S.C.A., 2nd Cir.), certiorari denied, 58 S. Ct. 50, 302 U.S. 728.

86. Biggs v. Norfolk Dredging Co. (1966) 360 F. 2d 360 (U.S.C.A., 4th Cir.). There are, however, cases to the contrary: Garrisey v. Westshore Marina Associates (1970) 469 P. 2d 590, Wash. App. 718. The decisions which state that acceptance of workers' compensation benefits does not bar actions against employers or third parties under federal law, including Maritime Law, are based on the paramountcy of U.S. federal law over state law. Could such decisions be extended to assert the supremacy of U.S. federal law, including U.S. Maritime Law, over foreign workers' compensation legislation? It may be wiser for claimants not to accept provincial Workers' Compensation benefits until such issues are cleared up by the U.S. courts. This, however, would be unrealistic where claimants are in serious financial need.

87. See generally Brainard's Cottonwood Dairy v. Industrial Commission (1932) 14 P. 2d 212, 88 A.L.R.659(S. Ct. Utah). The Newfoundland Workers' Compensation Board will probably be limited to suing third parties such as the rig-owner in the United States for injuries or deaths to the offshore workers to whose claims the Board has been subrogated under the Newfoundland Act. The Canadian employers and other parties covered by the Newfoundland Workers' Compensation Act would probably retain their tort immunity from suit by the Board even in United States courts. 
foundland Workers' Compensation Act preclude coverage of offshore drilling activities if it could be shown either that Newfoundland's general regulatory authority constitutionally extends to the continental shelf, or that the Act applies to all workers whose "usual place of employment" is Newfoundland, regardless of where the accident actually occurs.

Whether or not the extension of workers' compensation coverage to the offshore is intra vires the province of Newfoundland, it seems relatively clear that under the law as it presently stands (the rule in Phillips v. Eyre), an aggrieved party could not maintain an alternative tort action against the offshore employer in any common law jurisdiction in Canada. In either case the action is barred because the wrong is not actionable by the lex fori, or because the wrong is "justifiable" by the lex loci delicti, or both.

There is, however, a possibility that aggrieved parties may be able to maintain alternative tort actions against employers or their parent companies in United States courts. Providing that the courts find adequate reasons why the alleged wrongful act should attract United States jurisdiction, aggrieved parties may have access to wide statutory remedies under the federal Jones Act or the Death on the High Seas Act.

However these issues are resolved in Canadian courts and elsewhere, it should be obvious that the "transboundary" structure of frontier energy exploration in the offshore and high seas generally will make for challenging times for the legal advisors of our petroleum and mining companies. These companies may well wish to develop expertise in the constitutional law, maritime law, conflict of laws, and international law problems raised by our new era of frontier exploration, of which the problem of workers' compensation and alternative tort liability is but one vivid example.

\section{APPENDIX}

A. On July 2, 1982, the Newfoundland Legislature amended the Newfoundland Workers' Compensation $\mathrm{Act}^{\mathrm{88}}$ to expressly allow workers or their dependents to apply for and claim compensation and take legal action against third parties not covered by the Act. The new amendments do not affect the previous state of the law that prevents workers or their dependents from suing their employers. The amendments also permit the Newfoundland Workers' Compensation Board to be subrogated to the rights of a worker or his dependents and to bring an action against the third party not covered by the Act where no such action was brought by the workers or dependents within a reasonable time prior to the expiry of the limitation period.

The new amendments deal with the double recovery issue. First, the amendments stipulate that if workers or their dependents receive compensation payments and receive damages from court action, the workers or their dependents would be required to repay to the Newfoundland Workers' Compensation Board the amount received as compensation. Second, if the Workers' Compensation Board in exercising its right to subrogation receives in a court action an amount greater than the amount of compensation paid out to the claimants, the Board is required to pay the difference to the workers or their dependents.

The amended Section 11 now reads:

88. Bill 50, An Act to Amend the Workers' Compensation Act (1st Session, 39th Assembly, 1982). The Bill received Royal Assent on July 2, 1982. 
11 (1) Where an accident happens to a worker in the course of his employment in such circumstances as entitle him or his dependents to an action against some person other than his employer, the worker or his dependents, if they are entitled to compensation, may claim compensation and may bring an action.

(2) Where a worker referred to in subsection (1) or his dependents bring an action and less is recovered and collected than the amount of the compensation to which the worker or dependents would be entitled under this Act, the worker or dependents are entitled to compensation under this Part to the extent of the amount or amounts of the difference notwithstanding the time limits set out in paragraph (b) of subsection (6) of section 57.

(3) Where a worker referred to in subsection (1) or his dependents have claimed compensation and, prior to the expiration of the limitation period for the commencement of such action, have not commenced an action within a reasonable time as determined by the Board, the Board shall be subrogated to the rights of the worker or his dependents and may maintain an action in his or their names or in the name of the Board against the person against whom the action lies for the whole or an outstanding part of the claim of the worker or his dependents against such person.

(4) Where an action is commenced under subsection (1), the worker or dependents shall immediately serve notice in writing of the action, or where an action is commenced under subsection (3), the Board shall immediately serve notice in writing of the action to the worker or dependents, but in no case shall the failure to give notice as required by this subsection affect the claim as against the defendant.

(5) Where a worker or his dependents receive compensation under this Act and also receive an amount as a result of the commencement of an action in a court of law, the worker or dependents shall return to the Board the amount of compensation and the Board may, if the amount of compensation is not returned within a reasonable time, recover that amount from the worker or dependents as a debt due the Board.

(6) It is not obligatory upon the Board to sue for or require payment of damages caused by an accident referred to in subsection (1) unless it thinks fit to do so, and the Board may compromise the cause of action or release its claim therefor if, in its discretion, it thinks it inadvisable to bring action for the damages.

(7) A compromise settlement of any action by a worker referred to in subsection (1) or his dependents at an amount less than the compensation provided for under this Part is of no effect unless made with the approval of the Board.

(8) Where the Board is subrogated to the position of a worker or his dependents under subsection (5) and recovers and collects more than the amount of the compensation to which the worker or dependants would be entitled under this Act, the sum representing the amount of the excess, less costs and administration charges, shall be paid to the worker or dependents.

Other amendments to the Newfoundland Workers' Compensation Act passed on July 2, 1982 stipulate that the method of calculating compensation and the manner in which it is paid under the Act may be changed at any time by Order of the Lieutenant-Governor in Council. ${ }^{89}$ By similar order the limitation period within which a claim for compensation must be made can be extended. ${ }^{90}$ The amendments are deemed to have come into force on January 1,1982 . As the amendments only affect third parties not covered by the Act, they do not

89. Section 46 of the Newfoundland Workers' Compensation Act is amended by adding immediately after subsection (12) the following:

(13) The method of calculating compensation under this section and the manner in which compensation is paid under this section whether by lump sum, periodic payments or otherwise, may be changed from time to time by order of the Lieutenant-Governor in Council with effect from the date of the order, or such earlier or later date as may be set out in the order.

90. Section 57 of the Workers' Compensation Act is amended by adding immediately after subsection (6) the following:

(6.1) Notwithstanding paragraph (b) of subsection (6), the Lieutenant-Governor in Council may, by order, extend the limitation period for making a claim for compensation in respect of an accident described in the order, with effect from the date of the order or such earlier or later date as may be set out in the order. 
affect the substantive rights and liabilities of the employers of the offshore rig workers discussed above. These amendments were aimed at allowing the families of victims of the "Ocean Ranger" disaster to sue companies not covered by the Act, such as Mitsubishi Heavy Industries Ltd. of Japan, the company that built the rig, and to allow them to claim compensation if such actions are unsuccessful. The conflict of laws issues in this type of litigation against third parties not covered by the Act would be enormously complex and will not be dealt with here.

B. On August 19, 1982, a Bill which would amend the Jones Act to prevent Canadians from initiating compensation suits in United States courts for injury or death on U.S.-owned offshore rigs being operated in Canadian waters was approved by the Merchant Marine Committee of the U.S. House of Representatives. ${ }^{91}$ The bill was passed by both the House and the Senate on December 10, 1982,92 and at press time is awaiting Presidential approval. It is almost certain to be law by time of publication. The amendment would not, however, affect claims arising out of the "Ocean Ranger" disaster. The bill still permits access to the U.S. courts for U.S. residents and foreigners who can show that there is no legal remedy in their own country or in the country in whose jurisdiction the injury or death occurred. ${ }^{93}$

The prime sponsor of the bill, Democrat Mario Biaggi of New York, stated that the rationale underlying the bill is that non-U.S. residents often have legal recourse or compensation programs in their own countries or the countries where the rigs are operating. Therefore, Biaggi claimed, it would not be unfair to require such non-U.S. residents to seek compensation in these other jurisdictions. ${ }^{94}$ The bill has been backed by U.S. rig-owners and the insurance industry. The amendment will clear up much of the uncertainty concerning the jurisdiction of U.S. courts to hear suits by foreign offshore rig workers discussed in Part IV of this article.

91. Canadian Press Report, Toronto Globe and Mail, August 20, 1982.

92. Canadian Press Report, Toronto Globe and Mail, Dec. 14, 1982.

93. Supra n. 91.

94. Supran. 91. 